\title{
Surficial sediments and post-glacial relative sea-level history, Hamilton Sound, Newfoundland
}

\author{
J. Shaw and K.A. Edwardson \\ Geological Survey of Canada, Atlantic Geoscience Centre, Bedford Institute of Oceanography, \\ P.O. Box 1006, Dartmouth, Nova Scotia B2Y 4A2, Canada
}

Date Received September 28, 1993

Date Accepted April 4, 1994

\begin{abstract}
Hamilton Sound is a shallow, wave-exposed embayment on the northeast coast of Newfoundland. Four seismostratigraphic units are recognised: (1) bedrock (acoustic basement); (2) a unit with incoherent reflections, interpreted as Late Wisconsinan glacial diamicton or till, which in places forms small drumlins; (3) a thin, acoustically stratified, draped unit found in the deepest parts of the eastern sound, interpreted as glacimarine gravelly mud; and (4) an uppermost unit with an acoustically stratified, ponded facies, and a facies which can be acoustically incoherent. Unit 4 consists of sandy mud, muddy sand, sand and gravel, and results from reworking of units 2 and 3. Three types of seabed occur: (1) bedrock; (2) bouldery gravel or gravel, sub-angular to rounded, which overlies, and is derived from, glacial diamicton of acoustic unit 2 . The coralline alga Lithothamnion sp. coats some clasts on their upper surfaces and some clasts completely. This, together with the occurrence of gravel ripples in several areas, is evidence of intermittent sediment mobility; and (3) gravelly sand, sand, muddy sand, or sandy mud, located in basins. Seabed features in this zone include dunes, iceberg furrows and pits. The regional relative sealevel curve is constrained by two types of morphological evidence: rounded drumlin crests at depths below $19 \mathrm{~m}$ which would have been truncated if sea level had fallen below $-18.5 \mathrm{~m}$, and (wave-cut) terraces at depths of 17 to $21 \mathrm{~m}$. These data are indicative of a $-17 \mathrm{~m}$ lowstand of relative sea level. Radiocarbon dates from a vibracore suggest that the lowstand occurred prior to $8.6 \mathrm{ka} \mathrm{B.P.} \mathrm{During} \mathrm{the} \mathrm{lowstand} \mathrm{Fogo} \mathrm{Island} \mathrm{was} \mathrm{connected} \mathrm{to} \mathrm{the} \mathrm{mainland} \mathrm{by} \mathrm{a} \mathrm{narrow} \mathrm{isthmus.}$
\end{abstract}

Le détroit d'Hamilton est une baie peu profonde et exposée aux vagues sur la côte nord de Terre-Neuve. Quatre unités sismostratigraphiques sont distinguées : (1) la roche de fond (le socle acoustique); (2) une unité montrant des réflections désordonnées, interprétée comme étant un diamicton glaciaire ou un till du Wisconsinien tardif et qui forme localement de petits drumlins; (3) une unité mince et étendue, montrant une stratification acoustique et qui se retrouve dans les parties les plus profondes du segment est du détroit; cette unité est interprétée comme étant une boue graveleuse glaciomarine; et (4) une unité sommitale comprenant un faciès d'étendue restreinte, stratifié acoustiquement, et un faciès qui peut montrer un désordre acoustique. L'unité 4 consiste en boue sableuse, sable boueux, sable et gravier et provient du remaniement des unités 2 et 3 . Il y a trois types de fond marin : (1) la roche de fond; (2) du gravier à blocs ou du gravier, subanguleux à arrondi, qui recouvre et est dérivé du diamicton glaciaire de l'unité acoustique 2. L'algue corallienne Lithothamnion sp. recouvre certains clastes sur leur partie supérieure ou d'autres complètement. Cet élément, combiné à la présence d'ondulations dans le gravier à plusieurs endroits, est une indication d'une mobilité intermittente du sédiment; (3) du sable graveleux, sable, sable boueux ou boue sableuse, situés dans des bassins. Les caractéristiques du fond marin comprennent des dunes, des sillons tracés par les icebergs et des fosses. La courbe régionale du niveau relatif de la mer est basée sur deux types de données morphologiques: des crêtes de drumlins arrondies à des profondeurs supérieures à $19 \mathrm{~m}$ qui auraient été tronquées si le niveau de la mer avait baissé sous $-18,5 \mathrm{~m}$, et des terrasses (coupées par les vagues) à des profondeurs de 17 à $21 \mathrm{~m}$. Ces données indiquent un minimum du niveau relatif de la mer à $-17 \mathrm{~m}$. Les datations radiochronologiques du carbone d'un sondage suggèrent que ce minimum a eu lieu avant $8,6 \mathrm{ka} \mathrm{Av}$. Pr. À ce moment, l'île de Fogo était reliée à la terre ferme par un isthme étroit.

[Traduit par la rédaction]

\section{INTRODUCTION}

Under the auspices of the Canada-Newfoundland Cooperation Agreement on Mineral Development 1990-1994, six cruises were conducted in selected regions off the northeast coast of Newfoundland between 1990 and 1993 (Shaw and Wile, 1990; Shaw et al., 1990, 1992; Edwardson et al., 1992, 1993; D.L. Forbes et al., in preparation). The aim of the project was to determine the marine gold placer potential of shallow innershelf environments off northeast Newfoundland. The aims of the surveys were to map and sample surficial sediments on the inner shelf and to collect data which would further our understanding of relative sea-level changes since deglaciation.
This paper focuses on one of the areas surveyed, namely Hamilton Sound, which is located between the island of Newfoundland and Fogo Island (Fig. 1). The surficial sediments of this area were discussed briefly by Jenner and Shaw (1991). This region is of interest because it is representative of shallow, wave-dominated areas of the Newfoundland inner shelf. Our first objective in this paper is to describe the distribution and texture of Quaternary sediments within Hamilton Sound.

Our second objective is to present evidence for post-glacial sea-level change. Shaw and Forbes (1990a) collected data from the sandy coast between Hamilton Sound and Cape Freels which suggested that relative sea level dropped rapidly from the ma- 


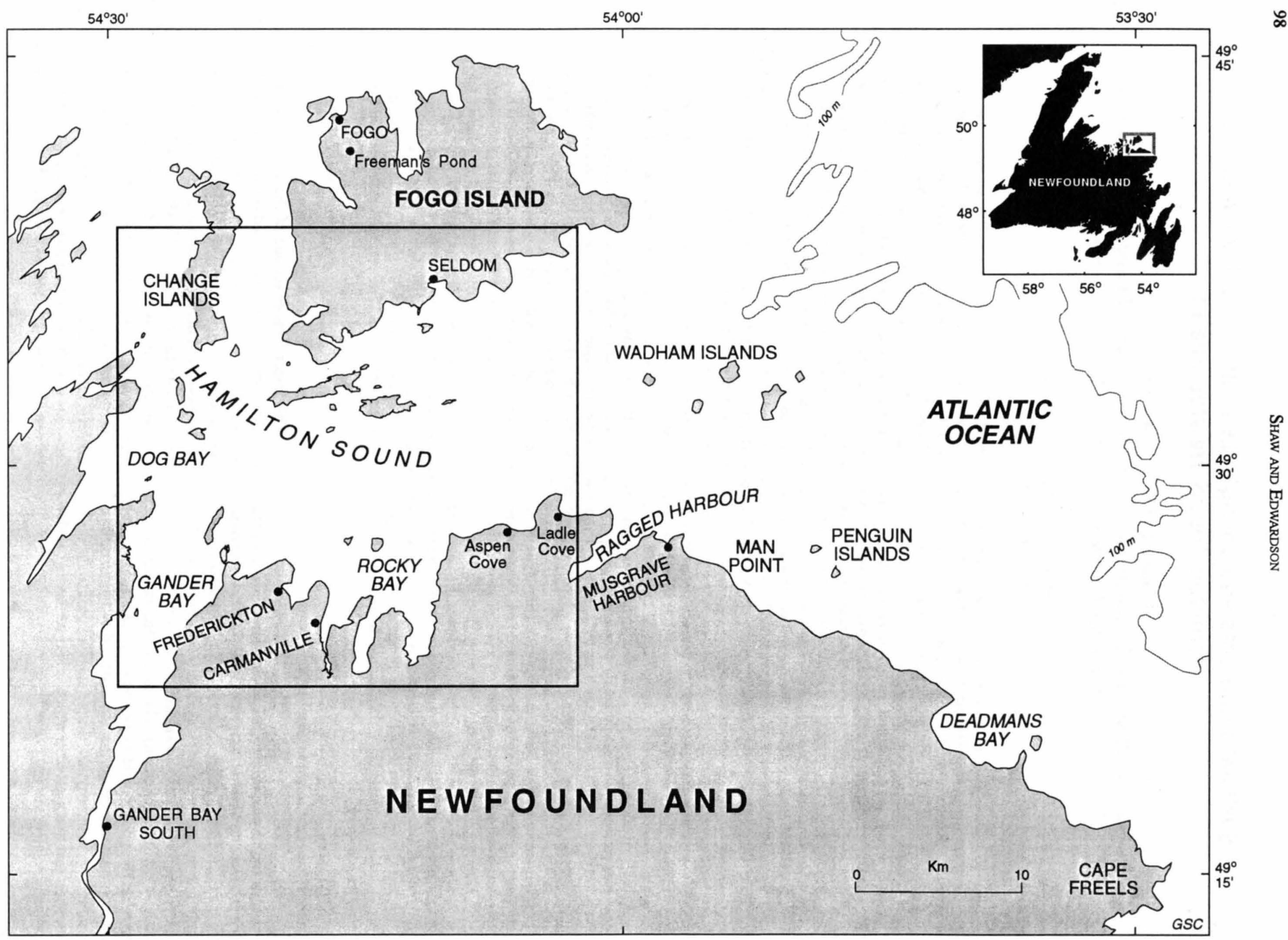

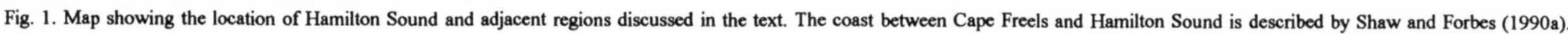


rine limit, fell below present sea level between 12.0 and $10.3 \mathrm{ka}$ B.P., and reached a minimum during the early Holocene. While the authors did not have sufficient data to define the depth of the postglacial lowstand, their data suggested that it was above $-25 \mathrm{~m}$. Relative sea level was still below $-4 \mathrm{~m}$ at $5.5 \mathrm{ka}$ B.P. but had reached approximately $-0.7 \mathrm{~m}$ by $3 \mathrm{ka}$ B.P. The questions addressed in this paper are firstly, what is the elevation and timing of the minimum post-glacial sea level?, and secondly, when did it occur?

\section{MeTHOdS}

Hamilton Sound was surveyed in 1990 using CSS Navicula (Shaw et al., 1990). Positions were obtained from both radar fixes and Loran $C$ time-distance measurements. Two surfacetowed shallow seismic reflection systems were used simultaneously: a Datasonics Bubble Pulser system and a Seistec highresolution system with a boomer plate sound source. The data were interpreted assuming a compressional sound velocity of $1.5 \mathrm{~km} \mathrm{~s}^{-1}$. Acoustic imagery of the seabed was obtained using a dual frequency (100 kHz and $500 \mathrm{kHz}$ ) Klein 595 sidescan sonar system, with a range set at $105 \mathrm{~m}$. Bathymetric data were obtained from Canadian Hydrographic Service Charts 4530 and 4531 , both at a scale of 1:40,000. Bathymetry, track lines, and sample locations are shown on Figures 2 and 3.

Thirty sea-bed samples were obtained with a van Veen grab sampler. Bottom photographs were taken at sample sites using a $35 \mathrm{~mm}$ camera contained in an aluminium housing. Grain size, multiple element geochemistry and gold grain analyses for grab samples were described by Emory-Moore (1991). For grain size analysis, sub-samples were wet sieved through a 0.063 $\mathrm{mm}$ mesh; the $>0.063 \mathrm{~mm}$ fractions were dry sieved.

In 1991, CSS Dawson was used to collect Huntec DTS highresolution seismic reflection data (Shaw et al., 1992). Two vibracores and several large-volume IKU grab samples were collected in the study area.

Table 1 contains information on radiocarbon dates obtained for this study, radiocarbon dates used by Shaw and Forbes (1990a) to define a relative sea-level curve for the northeast coast of Newfoundland, and dates from other sources discussed in the text.

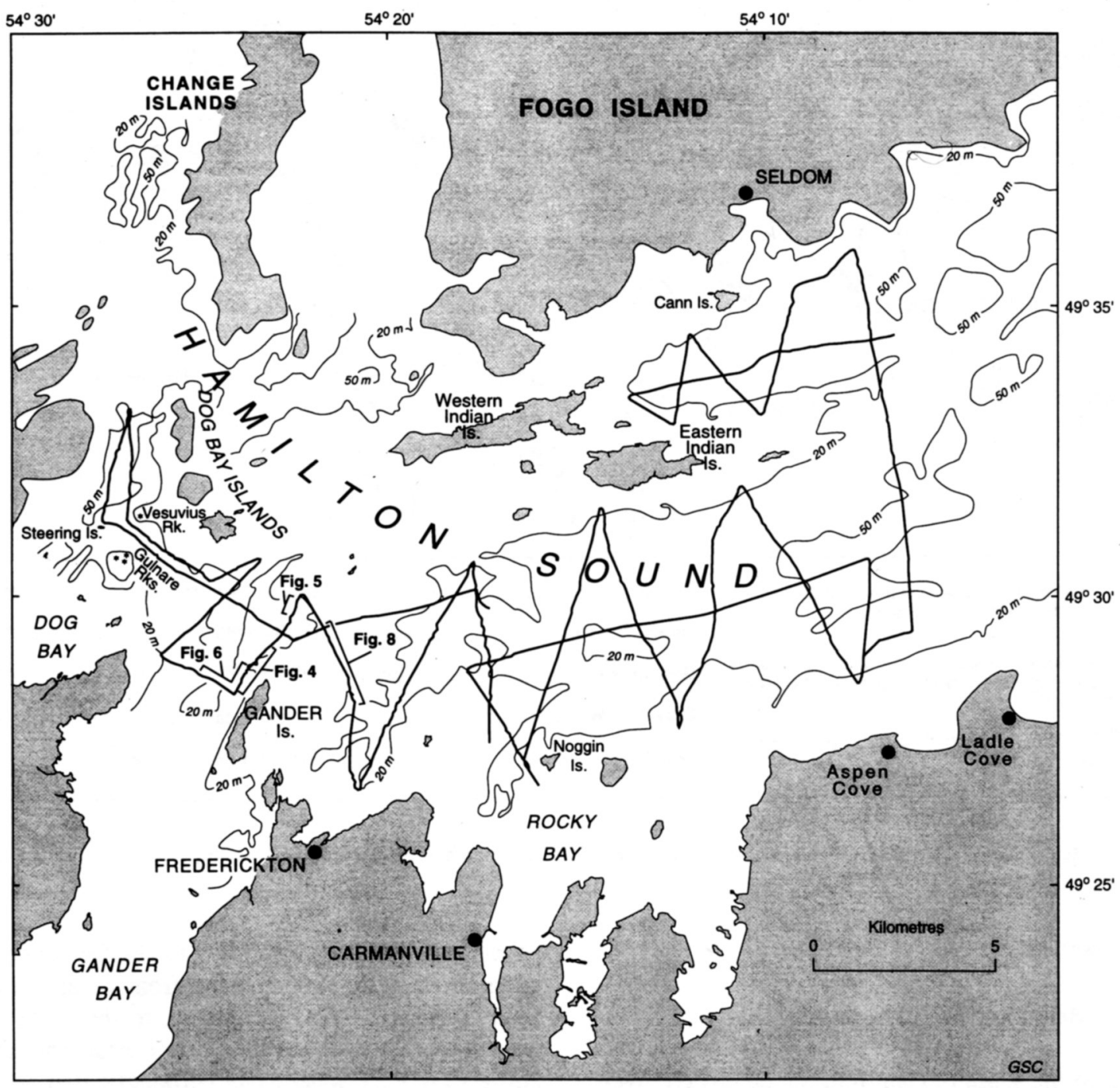

Fig. 2. Ship's tracks in Hamilton Sound for cruise 90-035, CSS Navicula, together with bathymetry and locations of Figures 4, 5, 6 and 8. 


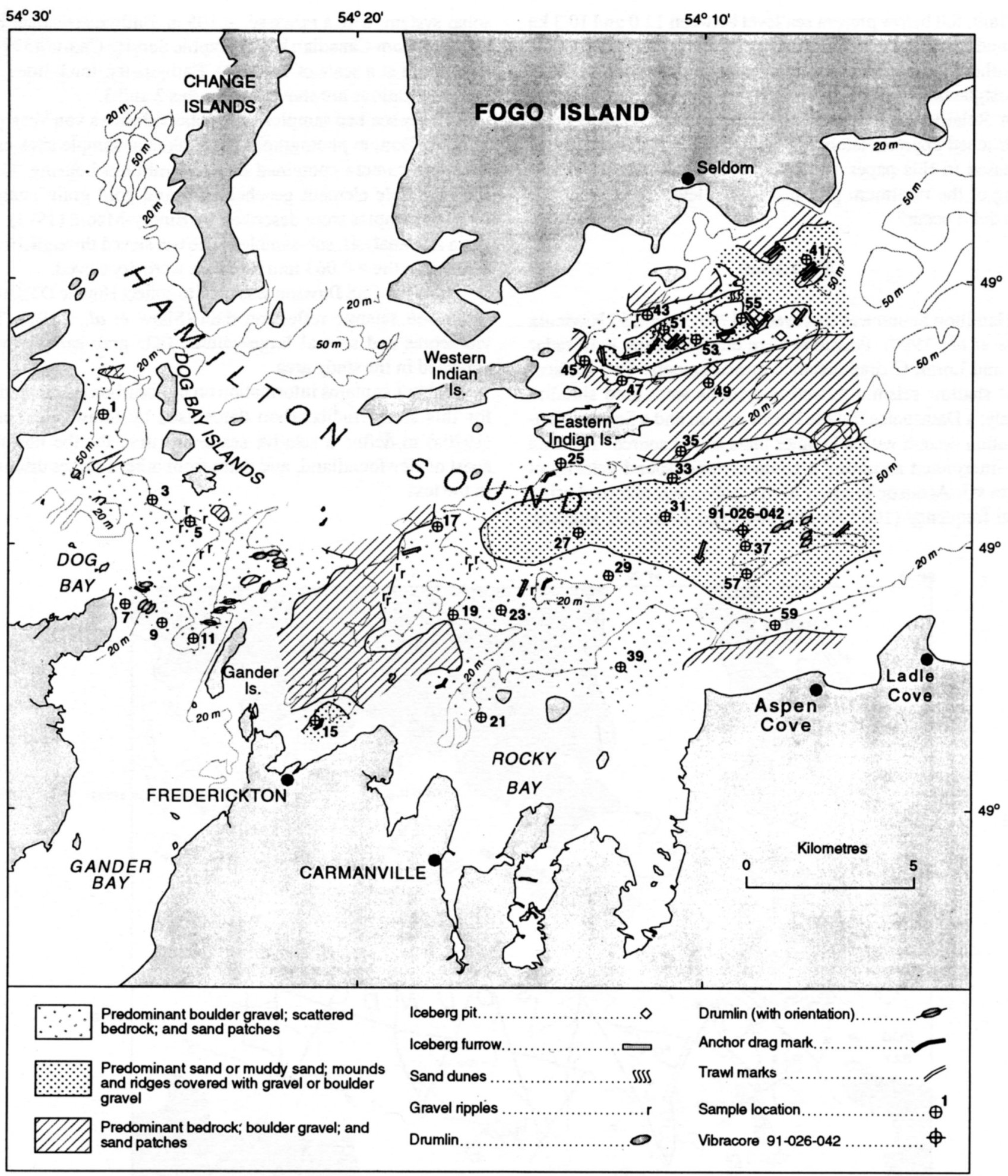

Fig. 3. Seabed characteristics in Hamilton Sound, also showing the locations of grab samples collected during cruise 90-035 and the location of vibracore 42 obtained on cruise 91-026, CSS Dawson.

\section{BACKGROUND TO THE STUDY}

\section{Relief and bedrock geology}

The region to the south of Hamilton Sound has relatively low relief, with a maximum elevation of just over $150 \mathrm{~m}$ approximately $25 \mathrm{~km}$ southeast of Carmanville. Farther west the physiography is dominated by the Gander River valley which maintains less than $50 \mathrm{~m}$ relief from $25 \mathrm{~km}$ upstream to the head of Gander Bay. Fogo Island, to the north of the sound, rises to over $90 \mathrm{~m}$ within $2 \mathrm{~km}$ of the coast. The survey area lies northeast of the Gander River Ultramafic Belt, within the Dunnage Zone. Cambrian to Middle Ordovician marine siliciclastic sedimentary rocks and limited exposures of Silurian and Devo- 
Table 1. Information on radiocarbon dates obtained for this study, radiocarbon dates used by Shaw and Forbes (1990a) to define a relative sea-level curve for the northeast coast of Newfoundland, and dates from other sources which are discussed in the text.

\begin{tabular}{|c|c|c|c|c|c|}
\hline $\begin{array}{c}\text { Age } \\
\left({ }^{14} \mathrm{C} \text { yr B.P. }\right)\end{array}$ & $\begin{array}{l}\text { Corrected for } 410 \\
\text { yr reservoir effect }\end{array}$ & Sample No. & Material & Location & $\begin{array}{l}\text { Elevation } \\
\text { (m) }\end{array}$ \\
\hline $210 \pm 50$ & - & GSC-4604 1 & FP & Man Point & +2.40 \\
\hline $1260 \pm 70$ & - & Beta-272341 & FP & Deadman's Bay & +0.67 \\
\hline $1630 \pm 50$ & - & GSC-45421 & FP & Cape Freels & +4.71 \\
\hline $1780 \pm 80$ & - & Beta-272331 & G & Deadman's Bay & -0.56 \\
\hline $2285 \pm 70$ & - & $\begin{array}{l}\text { Beta-361694 } \\
\text { (ETH-6375) }\end{array}$ & FP & Man Point & +0.85 \\
\hline $2740 \pm 60$ & - & GSC-45091 & FP & Man Point & +1.10 \\
\hline $2980 \pm 90$ & - & GSC-45921 & SMP & Man Point & -0.15 \\
\hline $3060 \pm 90$ & - & GSC-4662 1 & FP & Man Point & -0.10 \\
\hline $3150 \pm 90$ & - & GSC-4520l & FP & Man Point & +1.14 \\
\hline $5490 \pm 120$ & - & Beta-27231 1 & FP & Eastport & -3.30 \\
\hline $8140 \pm 80$ & - & GSC-48824 & W & Pound Cove & $\sim 0$ \\
\hline $9040 \pm 140$ & $8630 \pm 140$ & Beta-516754 & $S$ & Hamilton Sound & -55.4 \\
\hline $9700 \pm 85$ & $9290 \pm 85$ & $\begin{array}{l}\text { Beta-516764 } \\
\text { (ETH-9470) }\end{array}$ & $\mathrm{B}$ & Hamilton Sound & -55.5 \\
\hline $10,290 \pm 380$ & - & WAT- $888^{3}$ & W & Newtown & $\sim 0$ \\
\hline $11,000 \pm 260$ & - & GSC- $3973^{2}$ & G & Freeman's Pond & +56 \\
\hline- & $12,000 \pm 240$ & GSC-41821 & $\mathrm{S}$ & Parsons Point & $\sim 2$ \\
\hline $12,030 \pm 100$ & $11,620 \pm 100$ & $\begin{array}{l}\text { Beta-516774 } \\
\text { (ETH-9471) }\end{array}$ & $\mathrm{S}$ & Hamilton Sound & -56.6 \\
\hline $12,430 \pm 100$ & $12,020 \pm 100$ & $\begin{array}{l}\text { Beta-516724 } \\
\text { (ETH-9467) }\end{array}$ & $\mathrm{S}$ & Bay of Exploits & -82.0 \\
\hline
\end{tabular}

Beta shell dates are normalised to $\delta^{13} \mathrm{C}=25 \%$. ETH dates are AMS dates, adjusted by ${ }^{13} \mathrm{C}$ for natural isotope effect, and are also reported as Beta dates. Beta / ETH shell dates have been given a reservoir correction of 410 years, equivalent to fractionation correction to a base $\delta^{13} \mathrm{C}=0 \%$. GSC-4509 is unadjusted for $\delta^{13} \mathrm{C}$. GSC shell dates are reported already adjusted to $\delta^{13} \mathrm{C}=0 \%$. Materials coded as follows: $\mathrm{S}=$ shell; $\mathrm{B}=$ bryozoans; $\mathrm{FP}=$ freshwater peat; SMP = salt-marsh peat; $W=$ wood; $G=$ gyttja. ${ }^{1}$ Shaw and Forbes, $1990 \mathrm{a} ;{ }^{2} \mathrm{Blake}, 1987 ;{ }^{3}$ Davis and Wickham, $1987 ;{ }^{4}$ this study.

nian intrusive rocks predominate along the coast south of the sound (Colman-Sadd et al., 1990; Evans, 1991). Silurian and Devonian intrusives, Silurian siliciclastics and Late Ordovician to Early Silurian turbidites are the principal rock types north of the sound on Fogo Island (Colman-Sadd et al., 1990).

\section{Bathymetry and coastal geomorphology}

Hamilton Sound can be divided into three bathymetric regions (Fig. 2). The eastern region extends from just east of Frederickton, across the sound, to the west end of Eastern Indian Island, and east along Fogo Island to Cann Island. Mean water depth increases eastward toward the open shelf from 21 to $64 \mathrm{~m}$. The central region is a narrow zone which extends northeastward across the sound from the vicinity of Gander Island to Western Indian Island. This zone is shallower than 18 $\mathrm{m}$. The western region is located west of Gander Island and includes Gander and Dog bays. It deepens from $18 \mathrm{~m}$ near Gander Island to 80 m just west of the Dog Bay Islands. Water depths toward the mouths of Gander and Dog bays reach a maximum of about $48 \mathrm{~m}$.

The coastline bordering Hamilton Sound is mostly low and rocky with numerous small pocket gravel beaches confined by low headlands. The intertidal zone is strewn with large boulders in many areas. The largest gravel beaches occur within Ladle Cove, and include a small gravel barrier. The coastline changes character just east of the sound: from Musgrave Harbour southeastwards to Cape Freels (Fig. 1) it is sand-dominated, with barrier beaches, beach-ridge forelands, tombolos, and coastal dunes (Shaw and Forbes, 1990a).

\section{Oceanographic conditions}

Present conditions give some basis for understanding the impact of changing relative sea levels in the study area. Hamilton Sound is exposed to wave energy from the east and northeast. Northeast wave energy, approaching from between Fogo Island and the Wadham Islands (Fig. 1), penetrates well into the west- 
ern part of the sound. Neu (1982) showed that the largest significant wave height for a normal year east of the study area is 9 $\mathrm{m}$, with a maximum significant wave height of $11 \mathrm{~m}$, based on 11 years of Meteorological and Oceanographic Centre data collected from 1970 to 1980 . A sea ice cover of more than $40 \%$ is normally present by January 31 and remains until after April 30. Wave energy dominates within the ice-free months between June and December but is reduced in June and July by extensive patches of drifting pack ice. Icebergs are common in the early and middle summer. In late June and early July 1991 up to a hundred were observed just outside the entrance to the sound, many of them grounded (Shaw et al., 1992). Tides within the sound are semi-diurnal, with a mean tidal range of $0.9 \mathrm{~m}$ and a large tidal range of $1.5 \mathrm{~m}$. Ebb and flood currents in the centre of the eastern region are 1.0 and 0.5 knots, respectively.

\section{Quaternary sediments}

The till cover contiguous to Hamilton Sound is variable. Southwest of the sound along the coast (Liverman and Taylor, 1990; Munro, 1993), and north of the sound on Fogo Island, bedrock predominates, mostly concealed by patches of till or sand and gravel, usually less than $1.5 \mathrm{~m}$ thick. Bogs have accumulated in poorly drained low-lying areas. The regions inland from the southwest coast and the southeastern margin of the sound are characterised by a blanket of till up to $20 \mathrm{~m}$ thick. These thicker deposits form hummocks and elongated ridges (Jenness, 1960; Liverman and Taylor, 1990; Munro, 1993). Limited thin glacimarine deposits are restricted to Gander Bay.

Striation mapping by St. Croix and Taylor (1991) suggest four shifting centres of ice dispersion, three of which influence the region of Hamilton Sound. Ice in the oldest event flowed across the region in an easterly direction (Jenness, 1960; St. Croix and Taylor, 1991). Subsequent episodes indicate a more northward flow, from centres south and west of Gander.

The surficial sediments in Notre Dame Bay were mapped by Dale and Haworth (1979), using the new high resolution Huntec DTS and other tools (see Haworth, 1975, 1978). They showed that bedrock was overlain by till, semi-stratified and stratified units, and an uppermost acoustically transparent unit. These deposits were interpreted as having been deposited continuously "from a time prior to the last glacial retreat to the present day" (Dale and Haworth, 1979, p. 361). The chronology of sediment deposition is somewhat uncertain, as micropaleontological examination of cores has revealed problems in radiocarbon dating of total organic matter samples from the northeast Newfoundland inner shelf (Mudie and Guilbault, 1982). For example, Scott et al. (1984) reported a 4000 year discrepancy at one level between the radiocarbon age and that according to the pollen assemblage.

Jenner and Shaw (1991) showed that Hamilton Sound contains thin glacial diamictons capped by bouldery gravel, with sand in deeper basins; the relatively thick Late Wisconsinan and Holocene sequences observed farther offshore are absent.

\section{Late Quaternary relative sea levels}

Marine sediments deposited during an early postglacial highstand of relative sea level occur in the study region, for example, along the east side of Gander Bay and east of Musgrave Harbour (Liverman and Taylor, 1990). The postglacial marine limit in the vicinity of Musgrave Harbour was given by Grant (1980) as +43 m. However, Catto (1993) reported a +67 m limit in the same region. The timing of the marine limit is uncertain. Scott et al. (1991) suggested that the highest $(+75 \mathrm{~m})$ marine deltas in Hall's Bay, to the west of the study area, could predate 12.47 ka B.P. Cumming et al. (1992) argued that ice had retreated inland from the present coast of nearby Bonavista Bay (the large embayment immediately southeast of the study area) by 12,790 B.P. At Leading Tickles, located on a peninsula between Seal Bay and New Bay, west of the study area, pioneer herb-shrub vegetation was established by about 13.5 ka B.P. (Macpherson and Anderson, 1985). Fogo Island was certainly ice free by $11,000 \pm 260$ B.P. (GSC-3973), when basal lake sediment was being deposited at Freeman's Pond (see commentary by J.B. Macpherson, p. 3 in Blake, 1987).

These data suggest that deglaciation and the maximum relative sea level at Hamilton Sound occurred in the period 12.5 to 13 ka B.P. Relative sea level dropped rapidly from the marine limit, falling below present datum between 12 and $10.3 \mathrm{ka}$ B.P. (Shaw and Forbes, 1990a) to an undetermined minimum during the early Holocene, but subsequently rose to $-2 \mathrm{~m}$ by $4 \mathrm{ka}$ B.P.

\section{Surficial Sediments of Hamilton Sound}

\section{Seismostratigraphy}

Four acoustic units are defined in the study area, on the basis of distinctive acoustic attributes, bedding styles, and unit geometry (for definitions of these criteria refer to Syvitski and Praeg, 1989).

\section{Acoustic unit 1 (bedrock)}

Bedrock forms acoustic basement, and is defined by a continuous, strong reflection. On sidescan sonograms bedrock exposures are recognised as highly reflective patches and knolls, sometimes strewn with large boulders. They occur throughout the study area, but are most common in a zone extending between Noggin Island and Western Indian Island, east of Eastern Indian Island, and north of Vesuvius Rock (Fig. 2).

\section{Acoustic unit 2 (glacial diamicton or till)}

Unit 2 is present throughout Hamilton Sound with notable deposits occurring at the mouth of Gander Bay. It overlies unit 1 and is characterised by strong incoherent internal reflections. In some areas it infills bedrock depressions; elsewhere, particularly at the mouth of Gander Bay, it has positive relief (see below). On average, it is 2 to $4 \mathrm{~m}$ thick. On sidescan sonograms, sea-bed exposures of unit 2 are mantled by bouldery gravel of acoustic unit 4 . This results in a dark-toned (reflective) appearance, with numerous light-toned shadows cast by boulders. Acoustic unit 2 was intersected in the base of core 91-026-042, where it consisted of subangular pebbles in a matrix of stiff, sandy silty clay. Based on similar deposits elsewhere which have 
been extensively sampled (see, for example, King and Fader, 1986), unit 2 is believed to be a glacial diamicton, or till, deposited in contact with Late Wisconsinan glacial ice.

At the mouth of Gander Bay, deposits of glacial diamicton occur as rounded, elliptical mounds rising up to $15 \mathrm{~m}$ above the surrounding seabed (Fig. 4). The mound in Figure 5 is typical. It is $200 \mathrm{~m}$ wide, $250 \mathrm{~m}$ long, and $10 \mathrm{~m}$ thick. Its crest, at a depth of $20 \mathrm{~m}$, is thinly veneered with bouldery gravel and rises 8 to $10 \mathrm{~m}$ above surrounding gravel deposits several metres thick. The long axis is oriented at $075^{\circ}$. A seismic reflection profile across several mounds in this area is shown in Figure 6. These landforms are interpreted as small drumlins produced by glacier-ice movement from the west-southwest, a flow direction consistent with the onshore ice-flow indicators mapped by St. Croix and Taylor (1991). Munro (1993) mapped two onshore drumlins or drumlinoid features along the eastern margin of the mouth of Gander Bay, and another on Gander Island. These features have long axes ranging from $345^{\circ}$ to $250^{\circ}$ and may be onshore equivalents of the marine features.

\section{Acoustic unit 3 (glacimarine mud)}

This unit is resolved only on the Huntec records obtained on cruise 91-026. Small basins between bedrock highs in eastern Hamilton Sound contain up to $4 \mathrm{~m}$ of an acoustically stratified, ponded to draped unit, with continuous, moderate-intensity internal reflections. It is separated from the overlying silty sand of unit 4 by an angular unconformity. Vibracore 91-026042 , collected in a depth of $55 \mathrm{~m}$, intersected unit 3 and revealed bioturbated silty clay with scattered subangular pebbles. A gastropod (Natica clausa) at $1.59 \mathrm{~m}$ depth in this core is dated at 11,620 \pm 100 B.P. (Table 1).

\section{Acoustic Unit 4 (postglacial gravel, sand, and muddy sand)}

The sediments of acoustic unit 4 overlie acoustic units 1 to 3 , and occur in two acoustic subfacies. The first subfacies oc- curs as a veneer up to $3 \mathrm{~m}$ thick. It has moderate intensity, continuous, coherent internal reflections in some places, but may have incoherent reflections elsewhere. It has a dark tone on sidescan sonograms. Seabed outcrops consist of gravel or bouldery gravel. This facies is interpreted as postglacial marine gravel, probably derived from the reworking of acoustic unit 2 by waves and currents.

The second acoustic subfacies contains moderate to low intensity continuous, coherent, onlapping reflections. On sidescan sonograms this subfacies of acoustic unit 4 has a light tone, indicating relatively low acoustic reflectivity. It occurs mainly in the eastern part of the study area, and in deeper parts of the sound; its distribution coincides approximately with the area of sand in Figure 3. On the fringes of this region the sand forms isolated bodies, or narrow, interconnecting bodies located in depressions ponded between highs formed by units 1 and 2 . However, in the deepest areas, in the centre of the bay and northeast of Eastern Indian Island, the sand is more extensive and mantles seabed irregularities of units 1 and 2 .

Grab samples, photographs and cores confirm that this subfacies consists of medium to fine sand or muddy sand. The upper $0.90 \mathrm{~m}$ of core $91-026-042$ contained silty sand with shell fragments, shell hash, scattered pebbles and concentrated layers of branching bryozoans. This subfacies of acoustic unit 4 is interpreted as a postglacial deposit which resulted from reworking of earlier Quaternary deposits by wave and current action.

\section{Seabed character}

The seabed in Hamilton Sound displays great spatial variation and complexity which is controlled by the distribution of the seismostratigraphic units described above. The zones shown in Figure 3 are highly generalised - spreads of bouldery gravel occur between bedrock outcrops in the bedrock zone, patches of sand occur in the gravel zone, and within the sand zone, ridges veneered with gravel protrude above the sand, and in some areas constitute up to $50 \%$ of the seabed.

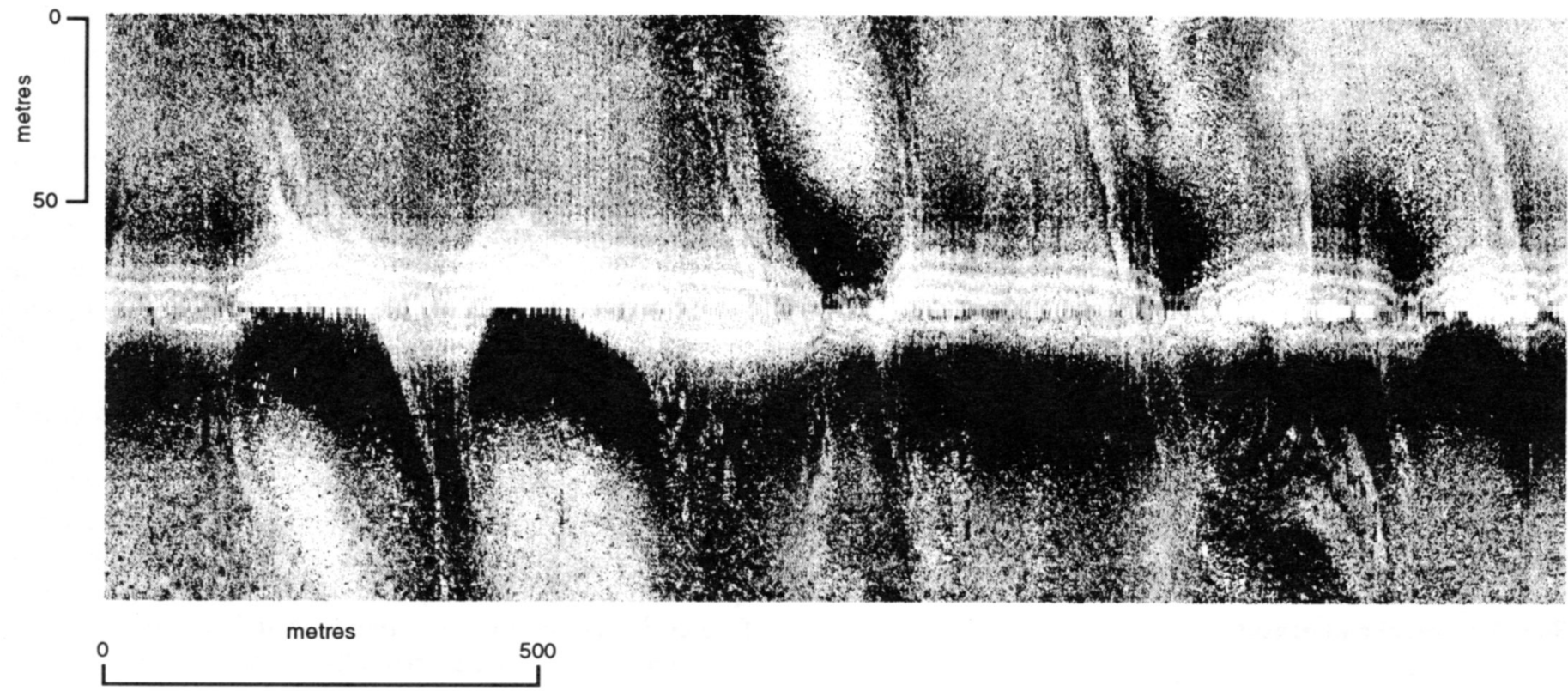

Fig. 4. Sidescan sonar image of a series of small drumlins northwest of Gander Island (location shown on Fig. 2). The orientation of the drumlins is 160 degrees. 

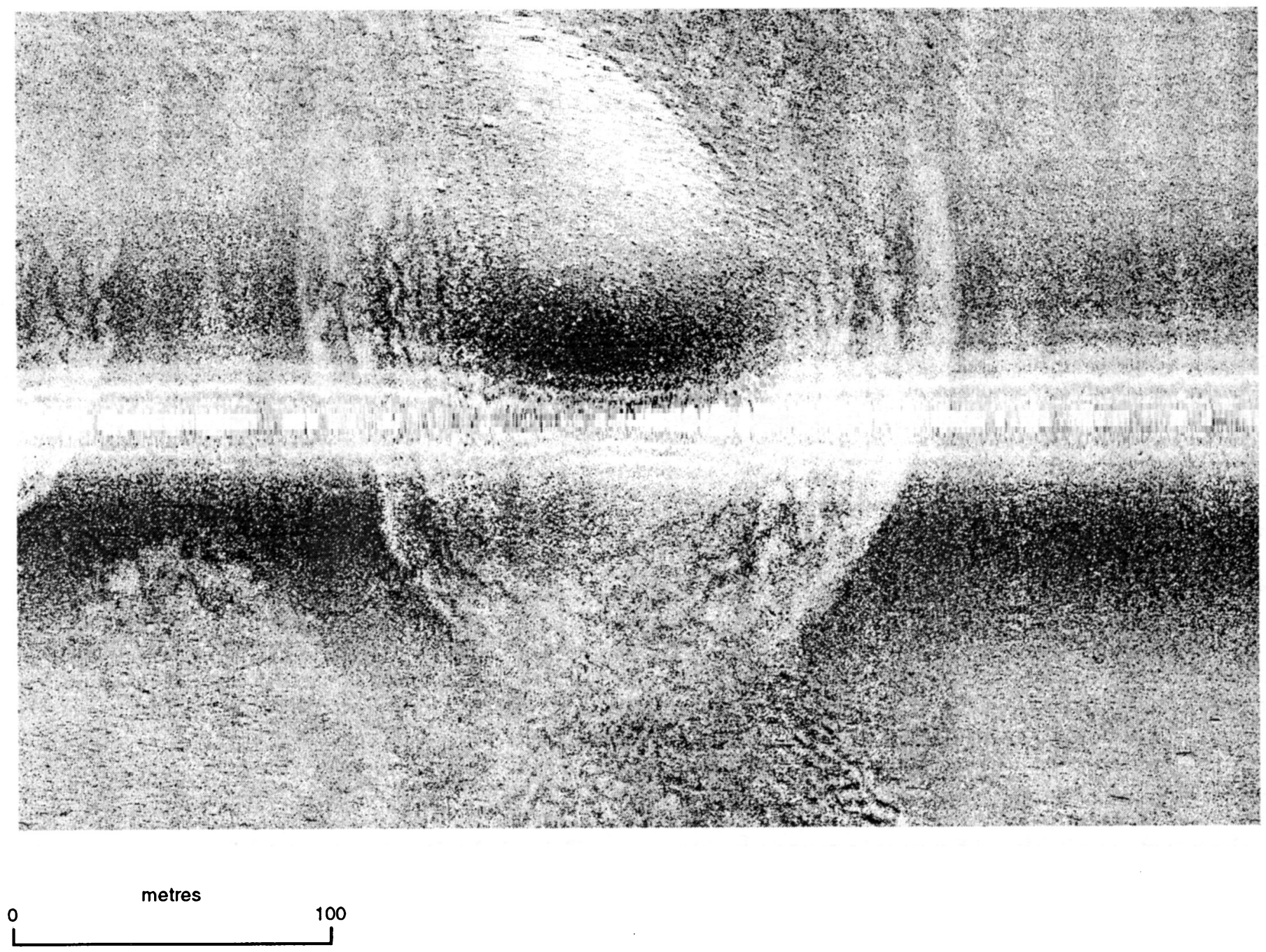

Fig. 5. Sidescan sonar image $(500 \mathrm{kHz})$ of a small drumlin, northwest of Gander Island, western Hamilton Sound (see Fig. 2 for location). The recorded data were played back, and recorded digitally. The digital data were then modified to remove the central strip and to rectify the image - it is now true to scale.

\section{Bedrock}

In this zone large numbers of bedrock outcrops (acoustic unit 1) occur on the seabed. The chief occurrences are: in a swath extending across the bay, from the mainland to Western Indian Island; immediately off the coast of Fogo Island and the eastern mainland coast (Ladle Cove area); on a ridge extending east from Eastern Indian Island; and in isolated locations in the west, e.g., Steering Island, Gulnare Rocks, and Vesuvius Rock (Fig. 2). Clusters of large boulders and patches of bouldery gravel are scattered throughout the bedrock zone: grab samples 90 035-035 and -049 yielded boulders and coarse subrounded to subangular gravel, heavily encrusted with Lithothamnion sp., and small amounts of coarse sand. The photograph at the site of sample 90-035-049 shows closely-packed poorly sorted gravel coated with Lithothamnion sp.

\section{Boulder-gravel and gravel}

This zone occurs both east and west of the shallow sill which extends from the mainland towards Western Indian Island, deeper than the bedrock zone but shallower than the sand/muddy sand zone (Fig. 3). The areas mapped as bouldery gravel are characterised by a gravel veneer overlying glacial diamicton. The gravel is subangular to subrounded, with clast long axes typically $<1 \mathrm{~m}$ and with no dominant clast shape. The gravel is coarse and bouldery on top of seabed highs but finer in depressions. IKU large-volume grab samples show that the gravel also occurs as a thin $(0.15 \mathrm{~m})$ layer overlying sand. Grain size data (Emory-Moore, 1991) show that the gravel ranges from granule to cobble size and contains between 10 and $55 \%$ sand. The mud content is consistently below $4 \%$.

Figure $7 \mathrm{a}, \mathrm{b}$ and $\mathrm{c}$ illustrates the variability of sorting and grain size within the boulder-gravel zone. Figure $7 \mathrm{a}$ (taken close to grab sample 90-035-001) is a photograph taken at $70 \mathrm{~m}$ depth west of Dog Bay Islands. It shows subangular pebbles and cobbles with a thin veneer of finer sediment. The photograph shown in Figure $7 \mathrm{~b}$ (close to grab sample 90-035-047) was taken in $24 \mathrm{~m}$ of water due north of Eastern Indian Island. The gravel clasts are subrounded to rounded, partially coated with the coralline alga Lithothamnion sp. and form a thin veneer on top of sand. Many of the clasts appear to have been overturned, and this is 

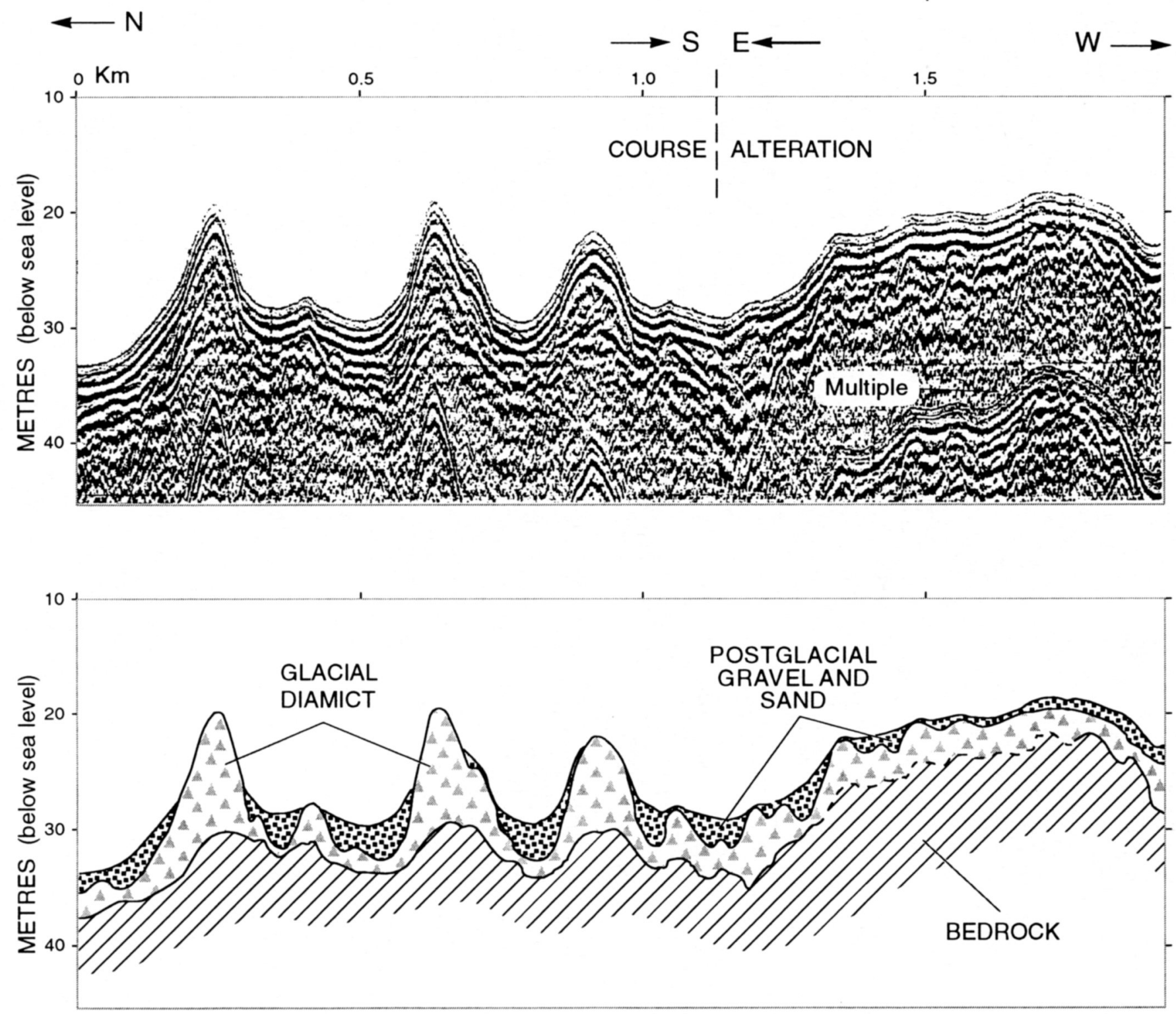

Fig. 6. Seistec high-resolution seismic reflection profile across drumlins at the mouth of Gander Bay (Fig. 2). The drumlins extend $15 \mathrm{~m}$ above the surrounding seabed.

interpreted as evidence for intermittent seabed mobility. The photograph shown in Figure 7c (grab sample 90-035-059) was taken in $41 \mathrm{~m}$ of water near Aspen Cove. The clasts are subangular to subrounded and do not appear to be overturned, suggesting less seabed mobility in this region.

There are some areas of mobile sandy gravel with few boulders, particularly in the western part of the sound, just southeast of Dog Bay Islands, for example. Sample 90-035-043 was collected off the south coast of Fogo Island in the vicinity of gravel ripples with $2 \mathrm{~m}$ wavelengths. It consists of a very poorly sorted mixture of sand and fine pebbles.

\section{Sand and muddy sand}

The seabed in this zone consists of sand or muddy sand, which appear light-toned (low acoustic reflectivity) on sidescan sonograms, in contrast with the dark tones of adjacent gravel areas. The distribution of this zone generally corresponds with that of the sandy facies of acoustic unit 4. It is found in the deepest part of Hamilton Sound, off the south coast of Fogo Island, and offshore from Frederickton.

The largest sand occurrence, in the central bay, is disrupted by gravel patches on its margins, but in the deepest areas the sand is so extensive as to completely mask underlying gravelcapped glacial diamicton. Samples from this region (90-035$027,-031,-037$ and -057 ) have variable grain-size distributions ranging from gravelly muddy sand (sample 90-035-027, depth $41 \mathrm{~m}$ ) to sandy mud (sample 90-035-037, depth $58 \mathrm{~m}$ ). In general, grain-size decreases with water depth.

North of Eastern Indian Island, sand fills topographic depressions and occurs as isolated patches on a gravel substrate the sand distribution is more patchy than in the central bay. Medium to large dunes (using the nomenclature of Ashley, 1990) occur in water depths of $36 \mathrm{~m}$ and have wavelengths which average $12 \mathrm{~m}$ and heights less than $0.5 \mathrm{~m}$. Crests are orientated north-south. Sample 90-035-051 was collected close to the dunes 

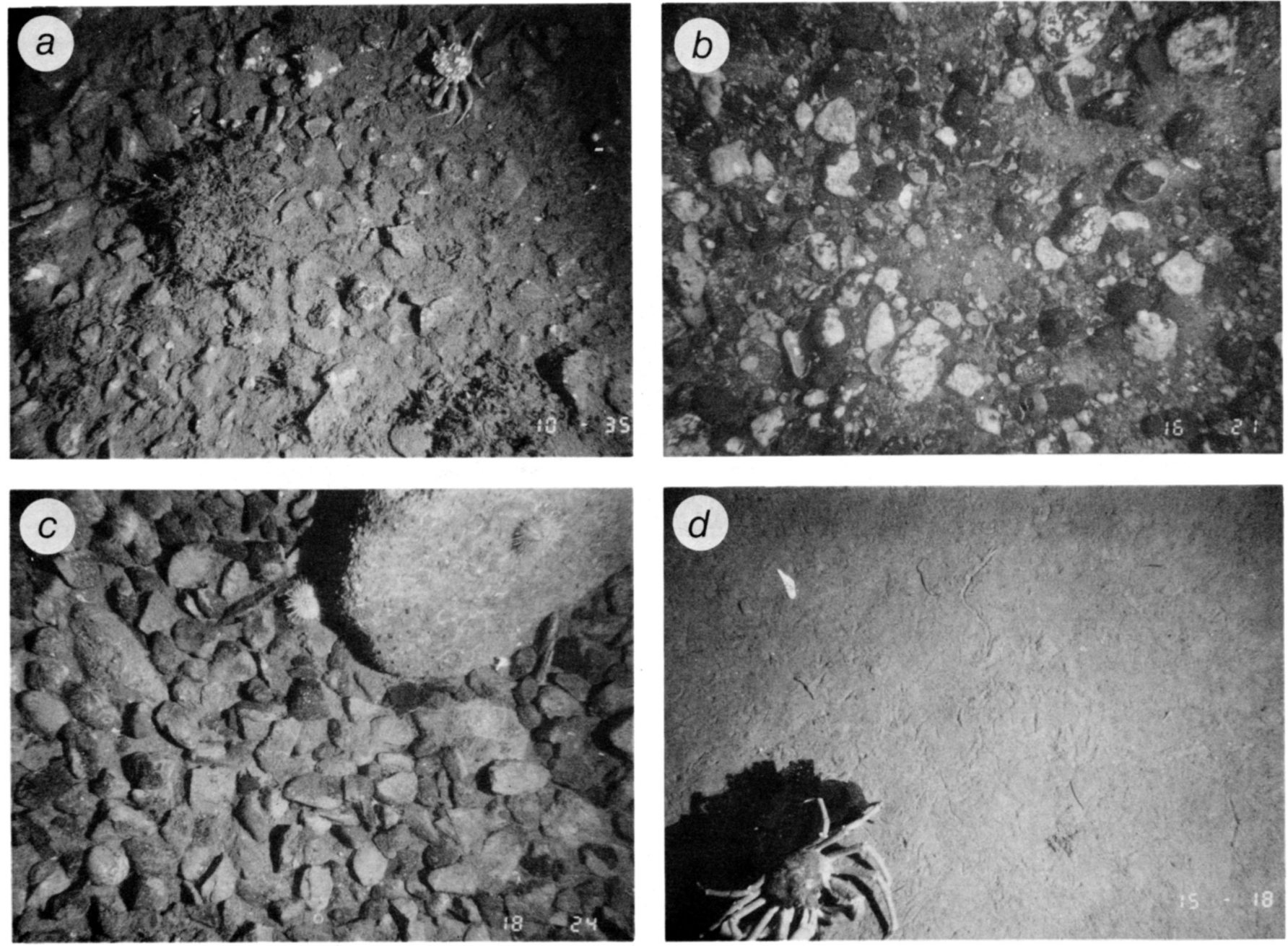

Fig. 7. Seabed photographs: (a) subangular gravel with a thin veneer of fine sediment, depth $70 \mathrm{~m}$, west of Dog Bay Islands (grab sample 1). Acoustic systems show a veneer of gravel up to several metres thick, over glacial diamicton. The absence of ponded sediment may be due to strong tidal flows; (b) rounded to sub-rounded gravel, wholly and partly coated with Lithothamnion sp., with sand in interstices, at a depth of 24 $\mathrm{m}$ (grab sample 47) north of Eastern Indian Island. This sediment is periodically mobile, and may have been moved during Hurricane Bertha on the 2 and 3 August 1990 (sample collected 5 August). The grab sample contained $50 \%$ sand; (c) a pavement of tightly packed subangular to subrounded gravel, much of it with a coating of Lithothamnion sp., at a depth of $41 \mathrm{~m}$ (grab sample 59). This material may be periodically mobile. The sample which was analysed contained about $50 \%$ sand, suggesting that the gravel is a surface veneer; (d) at a depth $50 \mathrm{~m}$ south of Fogo Island, showing a soft bottom scribed with trails. The accompanying grab sample (41) contained $47 \%$ fine sand and $44 \%$ mud.

and consisted of $2 \%$ gravel, $74 \%$ fine sand, and $24 \%$ mud. The bottom photograph of grab sample 90-035-041 (Fig. 7d) located off the coast of Fogo Island (Fig. 3) shows a fine bottom scribed with animal tracks.

The principal seabed features in this area (and to a lesser extent in the larger sandy region) are iceberg furrows and pits formed as a result of iceberg grounding. They are best preserved on gravelly substrates within this zone. The pits are shallow $(\sim 1 \mathrm{~m})$ depressions, typically $10 \times 10 \mathrm{~m}$ and circular to ellipti$\mathrm{cal}$ in planform. They are invariably infilled with sand, and the most recent ones have gravelly berms. Furrows are typically about $40 \mathrm{~m}$ long, straight to slightly curvilinear, and have a mean width of $5 \mathrm{~m}$ (the narrowest observed was $3 \mathrm{~m}$ ). A relatively wide furrow with triple berms was $18 \mathrm{~m}$ in width. Some furrows terminate in pits.

\section{Comparison with other parts of the northeast Newfoundland inner shelf}

Hamilton Sound is typical of shallow, gently-shelving, wave-dominated littoral areas on the northeast Newfoundland inner shelf. The width of this zone ranges from a few metres to a few kilometres. It includes, for example, the west coast of White Bay (Edwardson et al., 1992), off La Scie (Shaw, 1991), or the mouth of Baie Verte (Shaw, 1992). By contrast, the fjords in Notre Dame Bay (Bay of Exploits, New Bay, Badger Bay, Hall's Bay and Green Bay) are sheltered muddy basins with little wave activity at the seabed. Recent surveys (Edwardson $e t$ al., 1993) show that nearby Gander Bay also contains muddy sediments. However, while Hamilton Sound experiences higher wave energy than these areas, it is not the most exposed part of 
the region. The adjacent inner shelf, between the Wadham Islands and Cape Freels (Fig. 1), has the most extensive region of gravel ripples hitherto observed off eastern Canada. This sediment is highly mobile and has few coralline algal coatings.

\section{Deglaciation of Hamilton Sound}

Thin glacial diamictons deposited by Late Wisconsinan ice in Hamilton Sound are overlain in a few locations by equally thin deposits of glacimarine mud. This is in marked contrast to the deep fjords farther west in Notre Dame Bay (Bay of Exploits, New Bay, Badger Bay, Halls Bay and Green Bay) which contain thick (>150 m in places) sequences of stratified glacimarine sediment (cf. Jenner and Shaw, 1991). The relative thinness of the glacimarine muds in Hamilton Sound is mostly attributable to the energetic wave conditions which must have existed in the extremely shallow water. Also, the presence of thick onshore deposits of ice-proximal sand and gravel further west (Tucker, 1974; Scott and Liverman, 1991) suggests that large volumes of sediment-charged meltwater were released in fjords.

The radiocarbon date from acoustic unit 3 shows that open water existed in Hamilton Sound by 11,620 \pm 100 B.P. (Beta51677 / ETH-9471). However, evidence from elsewhere in the Notre Dame Bay region (see introduction) suggests that deglaciation occurred much earlier. A specimen of Hiatella arctica from $5 \mathrm{~m}$ below the seabed at a depth of $82 \mathrm{~m}$ in the Bay of Exploits, contained in gravelly clay (core 91-026-009; Shaw et al., 1992) has been dated at $12,020 \pm 100$ (Beta-51672 / ETH9467)). This sample is from the upper part of stratified glacimarine sediments which are $45 \mathrm{~m}$ thick, so potentially the retreat of late Wisconsinan ice inland of the present coast occurred earlier than 12 ka B.P., and perhaps close to the $\sim 13 \mathrm{ka}$ B.P. suggested by Cumming et al. (1992) for nearby Bonavista Bay.

\section{EVIDENCE FOR A POSTGLACIAL RELATIVE SEA-LEVEL LOWSTAND}

\section{Depth of the lowstand}

Shaw and Forbes (1990a) argued that relative sea level had fallen below the present level by the early Holocene. Two lines of reasoning are used in this paper to constrain the elevation of the minimum postglacial sea level. Firstly, clusters of small drumlins occur in the western part of the sound (see Fig. 3). Those illustrated in Figure 6 are typical and consist of glacial diamicton 11 to $14 \mathrm{~m}$ thick. Their surface is coarse bouldery gravel; intervening depressions contain finer gravel. The shallowest crest is $19.0 \mathrm{~m}$ below mean sea level. The drumlins have not been trimmed by wave action, and it is reasonable to conclude that their crests were never exposed to wave action in the intertidal zone. Allowing for the $0.6 \mathrm{~m}$ range of large tides, postglacial relative sea level did not drop below $\sim 18.5 \mathrm{~m}$.

A second argument is based on the occurrence of submarine terraces which are recognised on bathymetric profiles at depths which average $17 \mathrm{~m}$ at five locations, 18 to $19 \mathrm{~m}$ at two others, and $21 \mathrm{~m}$ in the exposed eastern part of the sound. The terraces are distinguished by low gradients compared with deeper areas, and by subdued bedrock relief, with boulders and gravel up to several metres thick in pockets, overlying glacial diamicton in places (Fig. 8). We argue that the terraces were formed by wave action in the intertidal zone during a sustained lowstand of relative sea level; their depth suggests a relative sea-level stillstand at $\sim 17 \mathrm{~m}$.

\section{Timing of the lowstand}

The approximate timing of the sea-level minimum can be deduced by considering the evidence from vibracore 91-026042 collected in a water depth of $55 \mathrm{~m}$ in eastern Hamilton Sound (Fig. 3). The Huntec high-resolution seismic reflection profile at the core site (Shaw et al., 1992) shows a small basin containing acoustic unit 2 (glacial diamicton) overlain by the well-stratified acoustic unit 3 (glacimarine mud). Above a strong unconformity is a ponded deposit of acoustic unit 4 (postglacial muddy sand).

The core has a $0.10 \mathrm{~m}$ surface layer of dark olive brown silty mud, below which is $0.80 \mathrm{~m}$ of interbedded muddy silt, silty sand, and silty clay with a high content of bivalves and bivalve fragments, gastropods, scattered pebbles and concentrations of bryozoan fragments. A complete Mya truncata bivalve at $0.42 \mathrm{~m}$, in good condition, is dated at $8630 \pm 140$ B.P. (Beta-51675), and bryozoan fragments at $0.51 \mathrm{~m}$ are dated at $9290 \pm 85$ B.P. (Beta-51676; ETH-9470). The sediments down to $0.90 \mathrm{~m}$ correspond with acoustic unit 4 , which consists of postglacial sediments formed by wave reworking of earlier deposits.

From $0.90 \mathrm{~m}$ to $2.70 \mathrm{~m}$ the core consists of bioturbated silty clay with scattered subangular pebbles. A specimen of the gastropod Natica clausa at $1.59 \mathrm{~m}$ was dated at $11,620 \pm 100$ B.P. This interval is equated with acoustic unit 3, glacimarine mud. The stony diamicton below $2.70 \mathrm{~m}$ in the core is interpreted as acoustic unit 2 , glacial diamicton.

The unconformity at $0.90 \mathrm{~m}$, separating acoustic units 4 and 3, represents the maximum depth to which glacimarine sediments were reworked. Assuming that the formation of the unconformity coincided with the postglacial lowstand, then the lowstand would have occurred before about $9.3 \mathrm{ka}$ B.P., based on the age of the bryozoan fragments. However, the bryozoan fragments are likely allochthonous, while the Mya truncata was more likely to be in situ. Consequently, the date of $8630 \pm 140$ B.P. on the latter provides a more conservative constraint on the timing of the lowstand, which therefore probably occurred before $8.6 \mathrm{ka}$ B.P.

The relative sea-level curve deduced for the area (Fig. 9) is a revision of the curve published by Shaw and Forbes (1990a). Freshwater organic detrital material in a core collected behind a small barrier beach at Eastport, $70 \mathrm{~km}$ south of Cape Freels, is dated at $5490 \pm 120$ B.P. (Beta-27231) and shows relative sea level still below $-3.3 \mathrm{~m}$ at that time. Shaw and Forbes (1990a) collected samples from peat deposits overlying the prograded dune-ridge foreland at Man Point (Fig. 1). Radiocarbon dates on these samples extend back to $3150 \pm 90$ B.P. (GSC-4520), and include a date on salt-marsh peat (GSC-4592) which shows 

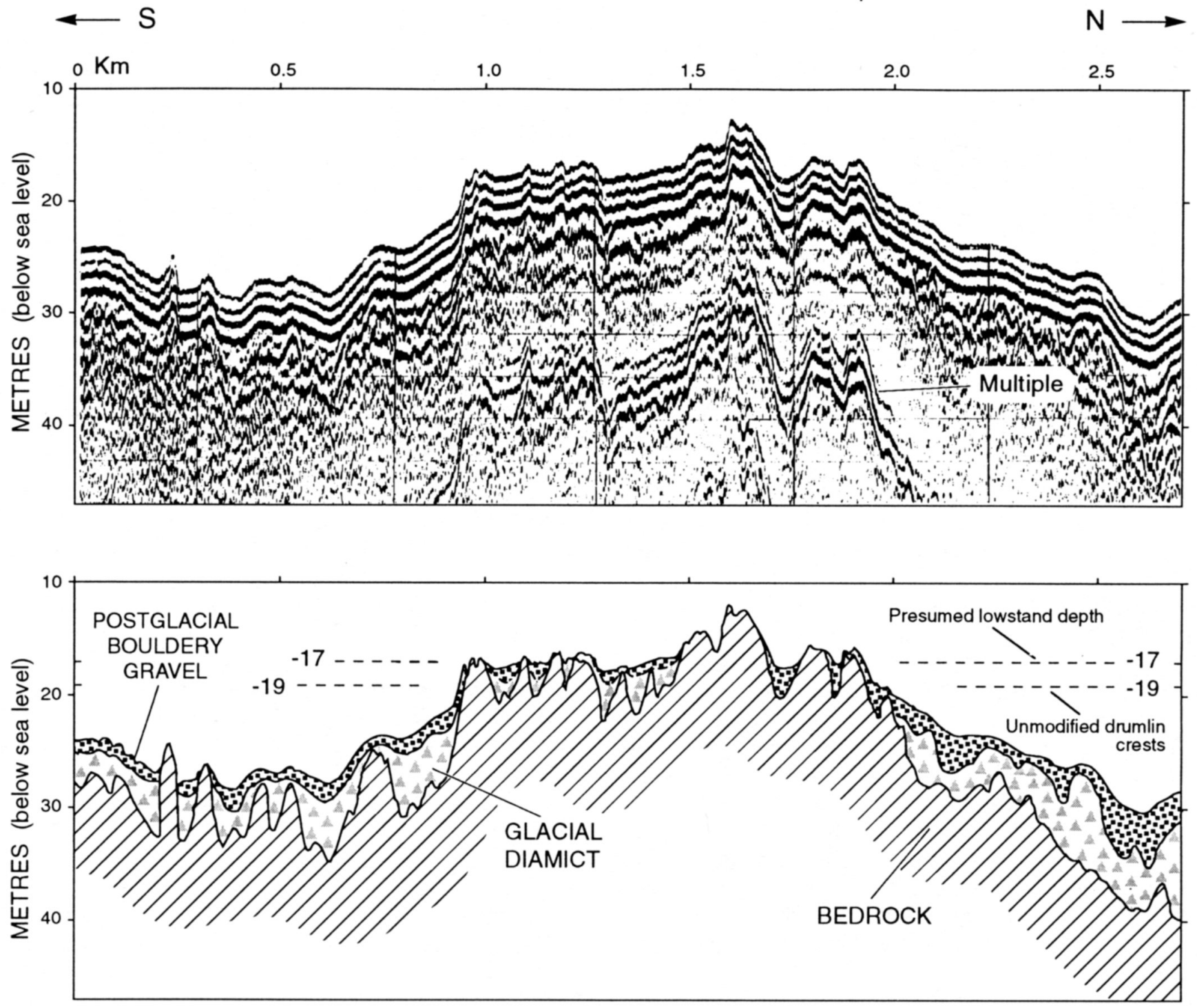

Fig. 8. Seistec high-resolution seismic reflection profile across a terrace north of Frederickton (location shown on Fig. 2). Depth of the terrace surface ranges from $15 \mathrm{~m}$ to $18 \mathrm{~m}$ below MSL. The surface is bouldery gravel with scattered bedrock outcrops. Below a depth of $18 \mathrm{~m}$ gravel completely masks bedrock or glacial diamicton. Because of the intense ringing (across $-6 \mathrm{~m}$ ) on Bubble Pulser records it is difficult to resolve the stratigraphy in detail.

relative sea level no more than $0.7 \mathrm{~m}$ below the present level at $2980 \pm 90$ B.P.

Two dates from nearby Deadman's Bay (Beta-27233 and 27234 , dated at $1780 \pm 80$ B.P. and $1260 \pm 70$ B.P., respectively) are from organic sediments overlying flood-delta deposits on a formerly transgressive barrier, and fit the overall pattern of sea-level rise of about $2 \mathrm{~m}$ since $4 \mathrm{ka}$ B.P., established by the Man Point dates.

Several new dates have been obtained onshore. A date of $8140 \pm 80$ B.P. (GSC-4882) has been obtained on an in situ stump of Abies balsamea from the coast near Pound Cove, Bonavista Bay, at mean sea level. It confirms that relative sea level was below datum at that time. An Accelerator Mass Spectrometry (AMS) date of $2285 \pm 70$ B.P. (Beta-36169 / ETH6375 ) was obtained on a small pocket of organic material within sandy dune ridges of the Man Point foreland. This is younger than dates on the base of the overlying peat (Shaw and Forbes, 1990a) and is most likely degraded root material. Information on the index points is contained in Table 1.

\section{Discussion}

The postglacial relative sea-level curve for Hamilton Sound (Fig. 9) is a type $C$ in the classification of Quinlan and Beaumont (1981). Type $C$ curves show an early high relative sea level, a drop to a postglacial minimum, and a subsequent rise. Forbes et al. (1993) discussed recent radiocarbon evidence from St. George's and Port au Port Bays, southwest Newfoundland, which showed that the postglacial lowstand in that area was $25 \mathrm{~m}$ at $9.5 \pm 1 \mathrm{ka}$ B.P. (see also Brookes et al., 1985; Shaw and Forbes, 1990b, 1992). Work in progress along the fiords of the south coast (Shaw et al., 1992) has revealed a series of sub- 


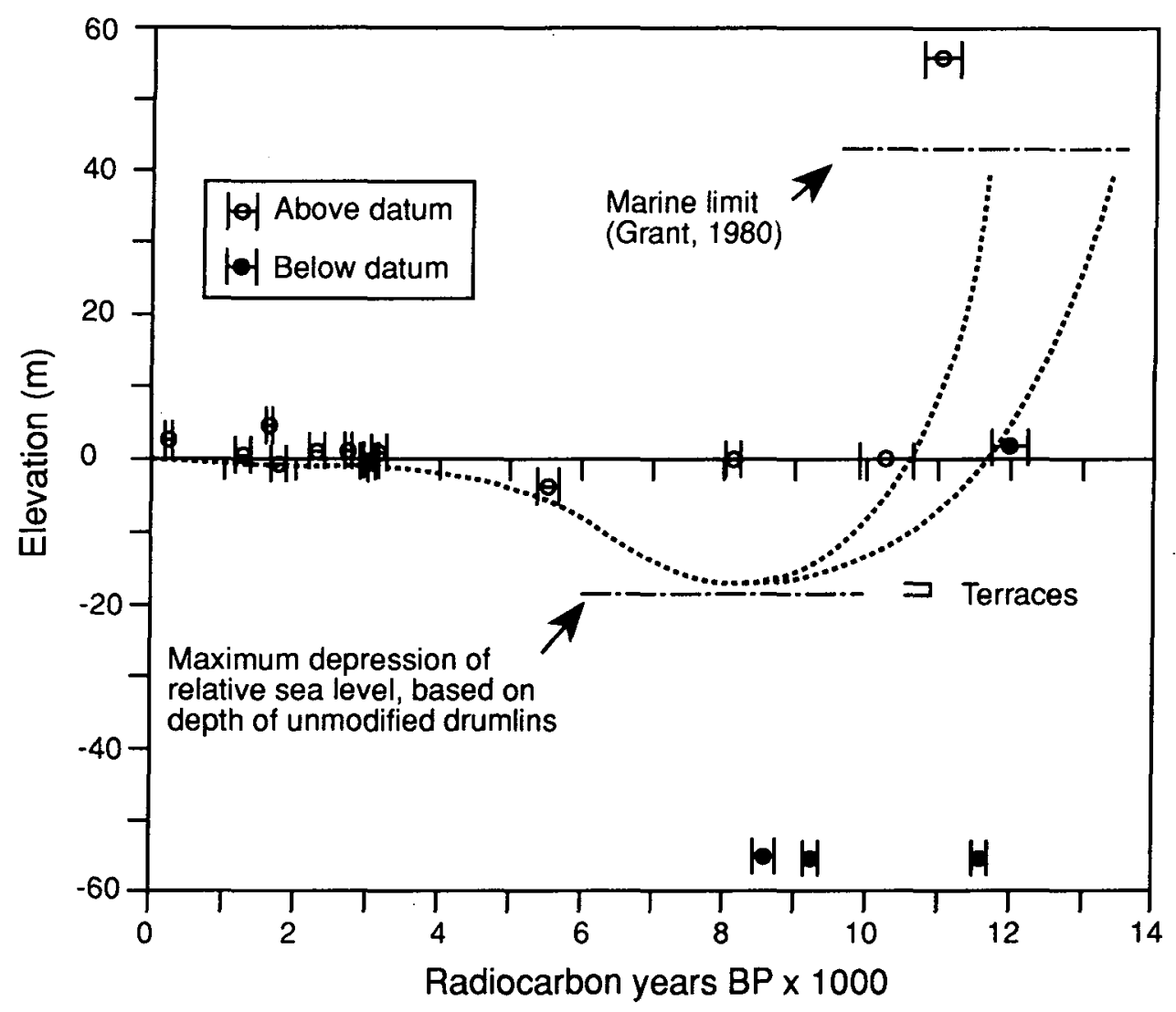

Fig. 9. Relative sea-level curve for the Hamilton Sound region. Data on index points are shown on Table 1. The marine limit is from Grant (1980); Catto (1993) reported a higher limit. The depth of the lowstand is constrained by unmodified drumlin crests at $-19 \mathrm{~m}$ and wave-cut terraces at depths between 17 and $21 \mathrm{~m}$. We are reasonably confident of the accuracy of the portion of the curve postdating $8 \mathrm{ka}$ B.P., but less so of the older part. Consequently, the pre- $8 \mathrm{ka}$ B.P. portion is represented by an envelope contained within the two lines.

merged fiord-head Gilbert-style deltas whose existence was suspected by Flint (1940). These register a relative sea-level lowstand which decreases in depth towards the interior of the island. When the data from the south coast and from other parts of Newfoundland (but not the Great Northern Peninsula, where submerged deltas are absent) have been fully analysed, it is expected that the spatial variation in lowstand depth and its possible diachronous nature will be more fully known. In the meantime, the relative sea-level curve for the Hamilton Sound area appears to fit well with the pattern of relative sea-level trends which is now emerging.

During the early Holocene sea-level lowstand the configuration of the coastline differed greatly from that of today (Fig. 10). When relative sea level dropped below $-14 \mathrm{~m}$, an isthmus formed, connecting the mainland with a large area of emergent land which included the present Dog Bay Islands, both Eastern and Western Indian islands, and Fogo Island. Gander Bay was protected from Atlantic swell and wind waves. The Wadham Islands were considerably expanded in area and must have protected the sound from easterly storm waves more than they do today. Fetch in the vicinity of the drumlins would have decreased to $12 \mathrm{~km}$ from the southwest and $6 \mathrm{~km}$ from the northwest, and the most southerly cluster of drumlins, beside Gander Island, would have been in the lee of a small island. Even with shorter fetches than today, we feel that the drumlins in Gander Bay would have been trimmed by wave action had the postglacial sea-level minimum exceeded $-18.5 \mathrm{~m}$. (Even in relatively sheltered estuaries, drumlins can be trimmed by wave action [Carter et al., 1992]). Beaches which may have existed on the isthmus and elsewhere during the lowstand were modified during the subsequent transgression when they were exposed to strong wave action.

\section{Conclusions}

(1) Hamilton Sound contains thin Quaternary sediments which, in comparison with other parts of the northeast Newfoundland inner shelf, amount to a very short record of Late Wisconsinan deglaciation. (2) The seabed of this shallow, wavedominated embayment contains coarse clastic sediments, principally gravel, with lesser amounts of sand. These result from reworking of thin glacial diamictons and glacimarine mud by waves, tidal currents, and icebergs. (3) We argue that the postglacial relative sea-level lowstand was $\sim-17 \mathrm{~m}$. This conclusion is based on (a) the occurrence of submerged drumlins at the mouth of Gander Bay with untrimmed crests below $-19 \mathrm{~m}$; and (b) the presence of submerged (wave-cut) terraces ranging from $-17 \mathrm{~m}$ to $-21 \mathrm{~m}$. (4) The lowstand commenced prior to $8.6 \mathrm{ka}$ B.P. (5) During the lowstand Fogo Island was connected to the mainland by a narrow isthmus extending north from Frederickton. Gander Bay was closed to circulation of ocean water from the east. 


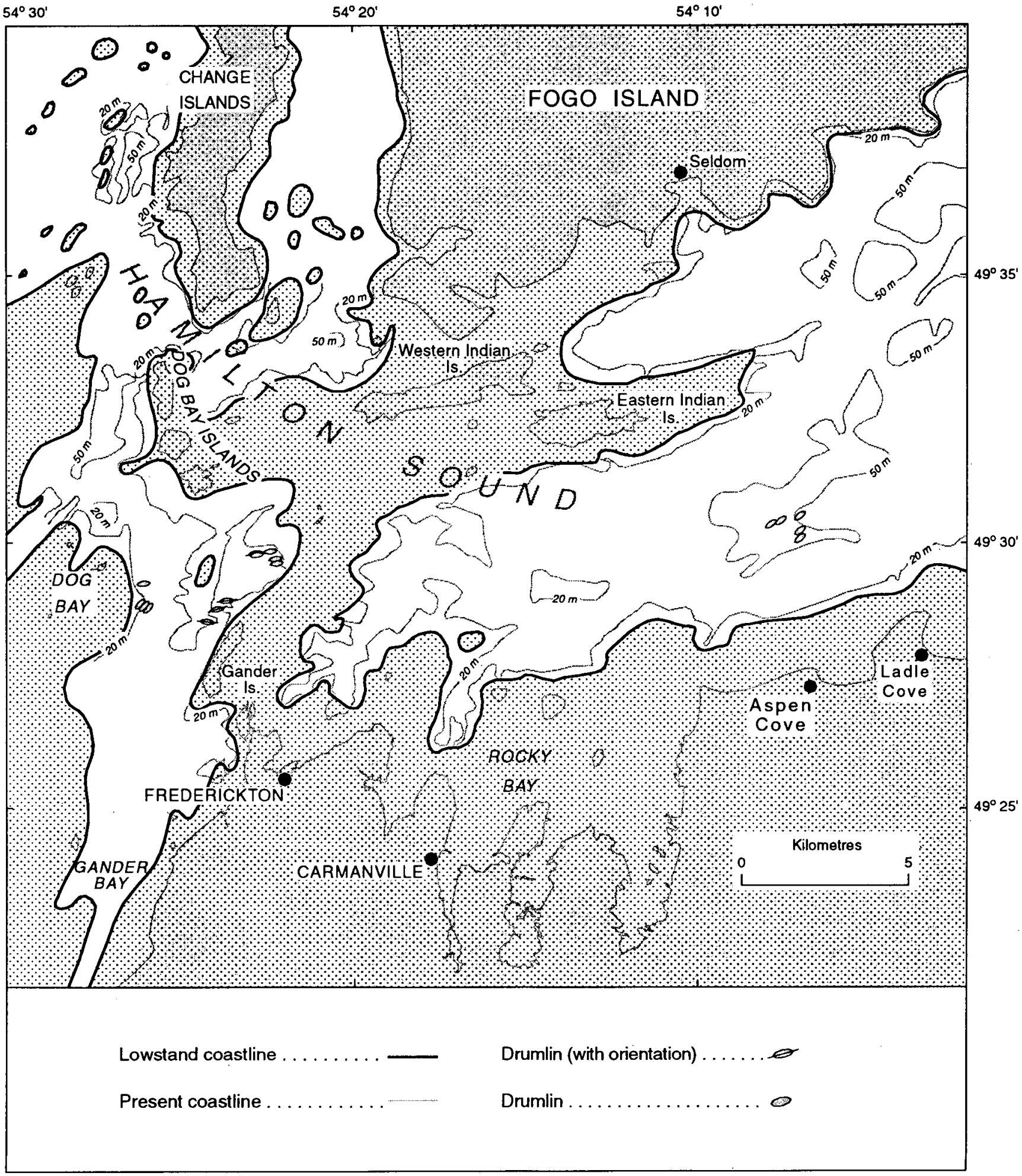

Fig. 10. The present coastline of the study area and the coastline during the early Holocene postglacial relative sea-level minimum. Also shown are the positions of drumlins (which were not emergent).

\section{ACKNOWLEDGEMENTS}

We are grateful to Captain J. Bray and the crew of CSS Navicula for their cooperation during cruise 90-035, and to Captain Hamish Berchem and the crew of CSS Dawson for their assistance during cruise 91-026. Technical contributions to fieldwork were made by Bruce Wile, Darryl Beaver, and Ken Asprey.
Hazen Russell participated in fieldwork and also assisted with data analysis. The manuscript was internally reviewed by R.B. Taylor and D.W. Piper. The research was funded in part by the Canada-Newfoundland Cooperation Agreement on Mineral Development (1990-1994). This is Geological Survey of Canada Contribution Number 32093. 
Ashley, G. 1990. Classification of large-scale subaqueous bedforms: A new look at an old problem. Journal of Sedimentary Petrology, 60 , pp. 160-172.

BLAKE, W., JR. 1987. Geological Survey of Canada radiocarbon dates XXVI. Geological Survey of Canada, Paper 86-7, 60 p.

Brookes, I.A., Scott, D.B., and McAndrews, J.H. 1985. Postglacial relative sea-level change, Port au Port area, west Newfoundland. Canadian Journal of Earth Sciences, 22, pp. 1039-1047.

Carter, R.W.G., Orford, J.D., Jennings, S.C., Shaw, J., and Smith, J.P. 1992. Recent evolution of a paraglacial estuary under conditions of rapid sea-level rise: Chezzetcook Inlet, Nova Scotia. Proceedings of the Geologists Association, 103, pp. 167-185.

CATto, N. 1993: Sea level variation in Newfoundland and Labrador glacio-isostatic, climatic, and anthropogenic. In The Scientific Challenge of our Changing Environment. Edited by J. Hall and M. Wadleigh. Report IR93-2, Canadian Global Change Program Incidental Report Series, Ottawa, 89 p.

Colman-SAdD, S.P., Hayes, J.P., and KNiGht, I. 1990. Geology of the Island of Newfoundland. Newfoundland Department of Mines and Energy, Geological Survey Branch, Map 90-01.

Cumming, E.H., Aksu, A.E., and Mudie, P.J. 1992. Late Quaternary glacial and sedimentary history of Bonavista Bay, northeast Newfoundland. Canadian Journal of Earth Sciences, 29, pp. 222-235.

DAlE, C.T. and HAWORTH, R.T. 1979. High resolution reflection seismology studies on late Quaternary sediments of the northeast Newfoundland continental shelf. In Current Research, Part B, Geological Survey of Canada, Paper 79-1B, pp. 357-364.

Davis, A.M. and WickhaM, S.M. 1987. The microstratigraphy of two peat sequences from northeastern Newfoundland. Géographie physique et Quaternaire, 41, pp. 355-364.

Edwardson, K.A., Shaw, J., Wile, B., and Prime, W. 1992. CSS Navicula operations in northeastern Newfoundland coastal waters: Ming's Bight, White Bay, Moreton's Harbour, Bay of Exploits and Twillingate Harbour. Geological Survey of Canada, Open File Report 2492, 14 p.

Edwardson, K.A., Forbes, D.L., Shaw, J., Johnston, L., Frobel, D., and LOCKE, D. 1993. Cruise Report 92-301. Nearshore and beach surveys along the northeast Newfoundland coast: Dog Bay, Gander Bay, Green Bay and Baie Verte. Geological Survey of Canada, Open File Report 2619, 29 p.

EMORY-MOORE, M. 1991. Gold placer potential of the northern Newfoundland shelf. C-CORE (Centre for Cold Ocean Resources Engineering) Contract Report 91-C7, prepared for the Geological Survey of Canada, $61 \mathrm{p}$.

Evans, D.T.W. 1991. Gold Metallogen, Eastern Dunnage Zone, Central Newfoundland. In Current Research, Newfoundland Department of Mines and Energy, Geological Survey Branch, Report 91-1, pp. 301-318.

FLINT, R.F. 1940. Late Quaternary changes of level in western and southern Newfoundland. Geological Society of America, Bulletin 51, pp. 1757-1780.

Forbes, D.L., Shaw, J., and EdDY, B.G. 1993. Late-Quaternary sedimentation and the postglacial relative sea-level minimum in Port au Port Bay and vicinity, west Newfoundland. Atlantic Geology, 29, pp. 1-26.

Grant, D.R. 1980. Quaternary sea-level change in Atlantic Canada as an indication of crustal delevelling. In Earth Rheology, Isostasy and Eustasy. Edited by N.-A. Mörner. John Wiley and Sons, London, pp. 201-214.

Haworth, R.T. 1975. Cruise Report Hudson 75-009. Bedford Institute of Oceanography, Dartmouth, Nova Scotia.

1978. Cruise Report Hudson 78-023. Bedford Institute of Oceanography, Dartmouth, Nova Scotia.

JENNER, K.A. and SHAW, J. 1992. Inner shelf Quaternary sediments off northeast Newfoundland. In Current Research, Part D, Geological Survey of Canada, Paper 92-1D, pp. 189-198.

JENNESS, S.E. 1960. Late Pleistocene glaciation of eastem Newfoundland. Geological Society of America, Bulletin 71, pp. 161-180.

KNG, L.H. and FADER, G.B.J. 1986. Wisconsinan glaciation of the Atlantic Continental Shelf of southeast Canada. Geological Survey of Canada, Bulletin 363, 72 p. and maps.

Liverman, D. and TAYLOR, D. 1990. Surficial Geology of Insular Newfoundland. Newfoundland Department of Mines and Energy, Geological Survey Branch, Map 90-08, preliminary version.

MacPherson, J.B. and Anderson, T.W. 1985. Further evidence of late glacial climatic fluctuations from Newfoundland: pollen stratigraphy from a north coast site. In Current Research, Part B, Geological Survey of Canada, Paper 85-1B, pp. 383-3,90.

Mudie, P.J. and GUILAUUT, J.-P. 1982. Ecostratigraphic and paleomagnetic studies of late Quaternary sediments on the northeast Newfoundland shelf. In Current Research, Part B, Geological Survey of Canada, Paper 82-1B, pp. 107-116.

Munro, M.J. 1993. Surficial geology and landform classification of the Carmanville map sheet (NTS 2E/8). Open File 2E/08 (0844), Map Number 93-13. Geological Survey Branch, Department of Mines and Energy, Government of Newfoundland and Labrador, St. John's. Scale 1:50,000.

NeU, H.J.A. 1982. 11-year deep-water wave climate of Canadian Atlantic Waters. Canadian Technical Report of Hydrography and Ocean Sciences No. 13, Department of Fisheries and Oceans, Ottawa, $41 \mathrm{p}$.

Quinlan, G. and Beaumont, C. 1981. A comparison of observed and theoretical postglacial sea level in Atlantic Canada. Canadian Journal of Earth Sciences, 18, pp. 1146-1163.

ST. CrolX, L. and TAYLOR, D. 1991. Regional striation survey and deglacial history of the Notre Dame Bay area, Newfoundland. In Current Research, Newfoundland Department of Mines and Energy, Geological Survey Branch, Report 90-1, pp. 61-68.

Scott, S. and Liverman, D.G.E. 1991. Sedimentology of Quaternary marine deposits in the Springdale - Hall's Bay area. In Current Research (1991), Newfoundland Department of Mines and Enengy, Geological Survey Branch, Report 91-1, pp. 69-78.

Scott, S., Catto, N., and Liverman, D.G.E. 1991. Quaternary marine deposits of the Springdale - Hall's Bay area, Newfoundland. Atlantic Geology, 27, pp. 181-191.

Scott, D.B., Mudie, P.J., Vilks, G., and Younger, C. 1984. Latest Pleistocene-Holocene paleoceanographic trends on the continental margin of eastern Canada: foraminiferal, dinoflagellate and pollen evidence. Marine Micropaleontology, 9, pp. 181-218.

SHAw, J. 1991. Quaternary sediments and seabed conditions offshore from La Scie, Newfoundland. Geological Survey of Canada, Open File Report 2385, 6 p.

- 1992. Surficial sediments of Baie Verte, Newfoundland. Geological Survey of Canada, Open File Report 2457, 14 p.

SHAw, J. and Forbes, D.L. 1990a. Relative sea-level change and coastal response, northeast Newfoundland. Journal of Coastal Research, 6, pp. 641-660.

1990b. Late Quatemary sedimentation in St. George's Bay, southwest Newfoundland: acoustic stratigraphy and seabed deposits. Canadian Journal of Earth Sciences, 27, pp. 964-983

1992. Barriers, barrier platforms, and spillover deposits in St. George's Bay, Newfoundland: paraglacial sedimentation on the flanks of a deep coastal basin. Marine Geology, 105, pp. 119. 140.

SHAw, J. and WILE, B. 1990. Surveys off northeast Newfoundland, including White Bay, Baie Verte, Green Bay, and Halls Bay: Report on final phase of cruise 90-013. Geological Survey of Canada, Open File Report 2311, 13 p. 
Shaw, J., Beaver, D.E., and Wile, B. 1990. Marine geological surveys in northeast Newfoundland coastal waters: Hamilton Sound, Baie Verte, La Scie, Halls Bay, Little Bay, Sunday Cove Island. Cruise Report 90-035. Geological Survey of Canada, Open File Report 2333, $18 \mathrm{p}$.

Shaw, J., Russell, H., Shern, A., and Atknnson, T. 1992. Cruise Report 91-026. C.S.S. Dawson operations in Newfoundland coastal waters: La Poile Bay to Bay d'Espoir, Notre Dame Bay, and Bay of Exploits. Geological Survey of Canada, Open File Report 2482, $23 \mathrm{p}$.

SYvitSk, J.P.M. and PrAEG, D.B. 1989. Quaternary sedimentation in the St. Lawrence Estuary and adjoining areas, eastern Canada: an overview based on high-resolution seismo-stratigraphy. Géographie physique et Quaternaire, 43, pp. 291-310.

TUCKER, C.M. 1974. A series of raised Pleistocene deltas in Hall's Bay, Newfoundland. Maritime Sediments, 10, pp. 1-7. 